Jurnal Ekonomi Syariah Teori dan Terapan p-ISSN: 2407-1935, e-ISSN: 2502-1508. Vol. 8 No. 5 September 2021: 537-547; DOI: 10.20473/vol8iss20215pp537-547

\title{
THE EFFECT OF POPULATION GROWTH AND TRADE OPENNESS ON ECONOMIC GROWTH OF THE OIC COUNTRIES
}

\section{PENGARUH PERTUMBUHAN PENDUDUK DAN KETERBUKAAN PERDAGANGAN TERHADAP PERTUMBUHAN EKONOMI NEGARA OKI}

\author{
Noor Syahro El Muharromy iD, Ilmiawan Auwalin \\ Departemen Ekonomi Syariah - Fakultas Ekonomi dan Bisnis - Universitas Airlangga \\ noor.syahro.el-2017@feb.unair.ac.id*, auwalin@feb.unair.ac.id
}

\begin{abstract}
ABSTRAK
Pertumbuhan ekonomi memegang peranan penting dalam menentukan keberhasilan pembangunan sebuah negara, oleh karena itu setiap negara selalu menetapkan target pertumbuhan ekonomi yang stabil dalam tujuan pembangunan. Dalam prosesnya pertumbuhan ekonomi dipengaruhi oleh berbagai factor yang dapat mendorong atau bahkan menghambat laju pertumbuhan. Penelitian ini bertujuan untuk menganalisis pertumbuhan penduduk, keterbukaan perdagangan, inflasi, nilai tukar dan investasi terhadap pertumbuhan ekonomi 40 negara anggota Organisasi Kerjasama Islam (OKI) pada tahun 2005-2019 menggunakan pendekatan kuantitatif dengan teknik analisis regresi data panel fixed effect model dan menggunakan aplikasi Eviews 11dalam mengelola data penelitian. Hasil penelitian ini menunjukkan bahwa variabel pertumbuhan penduduk dan nilai tukar memiliki hubungan signifikan dan negatif terhadap pertumbuhan ekonomi, sedangkan keterbukaan perdagangan dan investasi berpengaruh signifikan dan positif. Sedangkan investasi tidak berpengaruh signifikan pada pertumbuhan ekonomi di Negara OKI. Berdasarkan hasil penelitian ini pemerintah dan pihak terkait diharapkan dapat mengendalikan tingkat pertumbuhan penduduknya serta mendorong sektor perdagangan internasional untuk meningkatkan pertumbuhan ekonomi mengingat tingkat keterbukaan perdagangan di Negara OKI masih dibawah potensinya.
\end{abstract}

Kata Kunci: Pertumbuhan Ekonomi, Pertumbuhan Penduduk, Keterbukaan Perdagangan, Organisasi Kerjasama Islam.

\begin{abstract}
Economic growth plays an important role in determining the success of a country's development; therefore, each country always sets a target for stable economic growth in its development goals. In the process, economic growth is influenced by various factors that can encourage or even hinder the growth rate. The purpose of this study is to analyze the effect of population growth, trade openness, inflation, exchange rates and investment on the economic growth of 40 member countries of the Organization of Islamic Cooperation (OIC) in 2005-2019 using a quantitative approach with a fixed effect model panel data regression analysis technique and using the Eviews application. 11 in managing research data. The results of this study indicate that the variables of population growth and exchange rates have a significant and negative relationship to economic growth, while trade openness and investment have a significant and positive effect. Meanwhile, investment has no significant effect on economic growth in the OIC Country. Based on the results of this study, the government and related parties are expected to control the rate of population growth and encourage the international trade sector to increase economic growth considering that the level of trade openness in the OIC is still below its potential.
\end{abstract}

Keywords: Economic Growth, Population Growth, Trade Openness, Organization of Islamic Cooperation
Informasi artikel

Diterima: 12-04-2021

Direview: 03-06-2021

Diterbitkan: 30-09-2021

${ }^{*}$ Korespondensi (Correspondence):
Noor Syahro El Muharromy
Open access under Creative
Commons Attribution-Non
Commercial-Share A like 4.0
International Licence
(CC-BY-NC-SA) 


\section{INTRODUCTION}

The target in a country's development planning and goals is a stable economic growth as it reflects a success in its development, which generally measures the human living standards based on the number of goods and services available (Jhingan, 2000). The above growth involves an increase in the production capacity of the economy so that it will increase the national revenue of a country within a certain period of time. (Todaro and Smith, 2013).

In Islam economic growth is defined as the development of production factors which are sustainable and done in the right way so that they can contribute to human welfare. In Islam growth and equity are both simultaneously needed because, although Islam emphazises greatly on the importance of equity, the growth aspect cannot be ignored as it describes human welfare (Aprianto, 2017). This growth also involves the spiritual aspect for the purpose of achieving falah (victory and happines) in accordance with the word of Allah swt in QS. Al-Qashash: 77

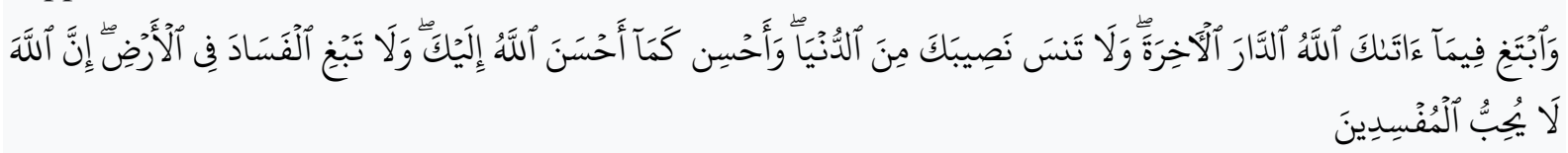

Meaning:" And seek by means of what Allah has given you (happiness) thefuture abode, and do not neglect your portionof this world, and do good (to others) as Allah has done good to you, and do not seek to make mischief in the land. Surely Allah does not love the mischief-makers."

One of the objectives of the agenda of "The OIC - 2025 Program of Action" during the period of 2016-2025 is to achieve sustainable development and to strengthen the economy of the OIC Countries, especially in terms of improving the socio-economic welfare of the community, considering the dynamic number of the population of the OIC Countries which are rich in natural resources and possess abundant human resources. In 2018, the GDP growth rate in the OIC countries decreased to $3.1 \%$ from $3.8 \%$ in the previous year. This growth rate is predicted to decrease up to $2.4 \%$ in 2019 which is still below the world average growth, and it will probably increase in 2020 (SESRIC, 2019).

Mankiw (2011), in his theory, explains that economic growth is also influenced by human resources (population), natural resources, physical capital, and human capital. The number of productive age population also grows each year, as stated by Sukimo (2013) that population continously growing can be both boosting economic development and an obstacle to economic development.

The data from the SESRIC (The Statistical, Economic and Social Research and Training Center for Islamic Countries) report states that the OIC members consist of 21 agrarian countries where 50 percent of the population works in agriculture and 17 oil-producing countries whose population earns per capita income four times higher than those from agrarian countries. The difference in per capita income in OIC member countries proves the large level of variation in GDP growth among these countries. Data from SESRIC (2020) notes that the average GDP growth rate per capita of the OIC during 2010-2015 grew by 2.2\%, then dropped to $1.3 \%$ during 2016-2019 below the world average. The per capita growth rate which is still below the global average shows that the standard of living in OIC countries is still relatively low compared to that of the other countries in the world. Poverty and unemployment rates in OIC countries are still relatively high among countries in the world.

In 2018, the OIC countries accounted for almost $24 \%$ percent of the world's total population, but the resulting GDP was only $15.2 \%$ of the world's total GDP (SESRIC, 2019). During the period of 2000-2018, the population growth in OIC countries got an annual average increase of $2 \%$ higher than the world population average (1.2\%), $1.1 \%$ in non-OIC developing countries, and $0.6 \%$ in developed countries. (SESRIC, 2020)

Dzian et al. (2020) states the current development of globalization will determine the direction of the world in the future. One of the most significant changes affecting the world economy for the last three decades is the rapid growth of integrated trade between countries' (Milani and Park, 2015). Due to globalization, countries are becoming more and more dependent on each others. Economic interdependence refers to the existing relationship between countries, where each country 
depends on each other for the goods or services needed. Export-import activities of goods and services are the characteristic of an open economy where the higher the level of openness, the greater the ability of the State to stimulate its economic growth (Mankiw, 2011). Becuase of that, international trade is one of the important catalysts for economic and social development. The trade openness ratio in this study is measured as the number of exports and imports of a country as part of a country's GDP in percentage units. The international trade volume of the OIC group of countries has increased since 2005 where exports, imports, and the total international trade volume index have increased, but their contribution to the global market is still below its potential (COMCEC, 2019).

Based on the above background, the writer was interested in conducting research on the OIC countries because its members are mostly developing countries with fluctuating economic growth rates. This study uses a sample of 40 OIC countries due to the availability of data collected from 2005-2019, where the OIC-Ten Years Program of Action agenda was first started in 2005 until 2019 when the last data was available. So, this research is expected to be able to contribute especially to policy makers in the OIC Countries as the evaluation materials regarding several factors affecting the OIC's economic growth over the last 15 years. As far as the writer knows, this is the first study to analyze the effect of trade openness and population growth on economic growth in the OIC Countries, which is different from the previous studies which were conducted based on the ranks of the countries. In addition, control variables, inflation, exchange rates and investment are taken into conisderation in the study in order to further develop the previous research. And for academic staff, the results of this research are expected to be used as knowledge, and the next researchers are expected to be able to conduct more comprehensive relevant research.

\section{THEORETICAL BASIS}

\section{Economic growth}

Economic growth is defined by Kuznets as an increase in the long-term capacity of a country to provide various types of goods and services to its population. Economic growth is manifestated in long-term or sustainable increases in output (Todaro and Smith, 2013). Economic growth in a country can move in a positive or negative direction calculated by comparing the current period with the previous period. The positive movement of economic growth is marked by an increase in per capita income, a decrease in poverty and a greater number of workers than the number of unemployed (Huda et al., 2017). The indicator used to measure the economic growth is real GDP which is the measurement of the whole goods and services at constant prices in the base year.

\section{Trade Openness}

International trade, export and import of goods and services, is the exchange of goods and services between two or more countries in the world market carried out by citizens of one country with those of other countries by mutual agreement with the other countries. Export-import activities carried out by a country have an important role, especially related to the growth of a country's economic activities because it is expected to provide benefits in terms of economy, socio-culture, and politics so as to be able to improve the domestic economy. The basic reason for having international trade is due to differences in technology, potential of natural resources, people's tastes, and efficiency between countries (Halwani, 2012). Meanwhile, according to Khalid (2016), trade openness is a contemporary effort to facilitate the exchange of goods and services, labor information, and capital.

The variable of trade openness used in this study measures the growth rate of total trade (accumulated exports and imports of goods and services) as part of a country's GDP in percentage units (World Bank, 2020) which can be written with the following formula:

\section{Population growth}

$$
T O(\text { trade openness })=\frac{\text { Eksport }+ \text { import }}{G D P}
$$

Population growth is an increase in the number of individuals in a population in a certain period of time. Since economic growth is the yardstick used to raise living standards worldwide, the role of population growth in the evolution of living standards is a significant policy issue (Peterson, 2017). Factors affecting population growth include mortality, fertility, and migration (BKKBN, 
2012). Increasing fertility rates in the long term can create a workforce that can encourage economic growth rates accompanied by skills training and good education (Kharis, 2011).

\section{Inflation}

Inflation is a symptom when prices in the economc life are increasing continuously in the long term caused by high demand for goods and services, an increase in money supply, and a rise in production costs. Inflation can have a positive or negative impact on real GDP when viewed from the side of demand and supply factors. According to Russiadi et al (2018), changes in the inflation rate can affect economic growth, because high and fluctuative inflation can harm economic growth (Baharumshah et al., 2016). In practice, Inflation is calculated based on a price index approach usually referred to as the consumer price index (CPI), producer price index (PPI), and the price index or GDP deflator. The effect of inflation on economic growth we can be measured by using the GDP deflator because it represents the overall price changes in the economy.

\section{Exchange rate}

Exchange rate is the relative value of the domestic currency to foreign currencies and vice versa used by citizens of the two countries in order to trade with each other. Since this includes two currencies, the equilibrium point is determined by the supply and demand sides of the two currencies respectfully. According to Hatmanu et al., (2020), exchange rate affects economic growth, one of which is from the view point of international trade. Exchange rate serves as one of the economic indicators in managing international trade because it reflects the benefits of the physical and commodity sectors and creates competitiveness in the global economy. On the other hand, exchange rate is very important because it helps in comparing goods and services issued around the world (Vorlak et al., 2019).

\section{Investment}

Investment can be defined as expenditures spent by investors or companies used to improve the ability to produce goods and services in the economic world (Sukirno, 2013). Domestic investment, or Gross Fixed Capital Formation (GFCF) serves as an indicator of the addition of gross productive assets created during a certain period. According to Haller (2012) GFCF is a component of GDP expenditure that measures the value of acquisitions of new or existing fixed assets by the business, government, and household sectors minus the disposal of fixed assets. GFCF is not a measure of total investment, because only the net added value of fixed assets is measured, and all types of financial assets as well as inventories and other operating costs are excluded. (Ikechi and Emmanuel, 2015).

Based on the explanation above, the hypotheses proposed in this study are:

1. H1: Population growth affects the economic growth of OIC members

2. H2: Trade openness affects the economic growth of OIC members

3. H3: Inflation rate affects the economic growth of OIC members

4. H4: The exchange rate affects the economic growth of OIC members

5. H5: Investment affects the economic growth of OIC members

6. H6: Population growth, trade openness, inflation, exchange rates and investment simultaneously affect the economic growth of OIC members

\section{RESEARCH METHOD}

The study uses quantitative approach using information or data in the form of numbers which is analyzed using statistical analysis (Sugiyono 2016). To process the data the writer uses panel data regression analysis technique with Fixed Effect Model and eviews 11 application as a tool to test. This study uses time series data for the period of 2005-2019 and cross section data for 40 OIC members based on the availability of the data.

Table 1

Sample of OIC countries

\begin{tabular}{|l|l|l|l|}
\hline \multicolumn{4}{|c|}{ Countries } \\
\hline Albania & Egypt & Kyrgyz & Pakistan \\
\hline
\end{tabular}


Muharromy, et al/Jurnal Ekonomi Syariah Teori dan Terapan Vol. 8 No. 5 September 2021: 537-547

\begin{tabular}{|l|l|l|l|}
\hline Algeria & Gabon & Lebanon & Saudi Arabia \\
\hline Azerbaijan & Gambia & Malaysia & Senegal \\
\hline Bangladesh & Guinea & Mali & Sierra Leone \\
\hline Benin & Guinea-Bissau & Mauritania & Sudan \\
\hline Brunei Darussalam & Indonesia & Maroko & Togo \\
\hline Burkina Faso & Iran & Mozambique & Tunisia \\
\hline Cameroon & Iraq & Niger & Turkey \\
\hline Chad & Jordan & Nigeria & Uganda \\
\hline Cote d'Ivore & Kazakhstan & Oman & UEA \\
\hline
\end{tabular}

Source: processed by the author (2021)

Population growth, trade openness, inflation, exchange rates, and investment serve as the independent variables in this study, and economic growth serves as the dependent variable. The formulation of the hypotheses to be studied gives the empirical model written as follows:

$\mathrm{GDP}_{\mathrm{it}}=\alpha_{\mathrm{it}}+\beta 1 \mathrm{POP}_{\mathrm{it}}+\beta 2 \mathrm{TO}_{\mathrm{it}}+\beta 3 \mathrm{INF}_{\mathrm{it}}+\beta 4 \operatorname{lnEXR}_{\mathrm{it}}+\beta 5 \mathrm{GFCF}_{\mathrm{it}}+\varepsilon_{\mathrm{it}}$

\section{Remarks:}

GDP : Economic growth (GDP per capita)

$\alpha_{\mathrm{i}} \quad$ : Constant coefficient

$\beta \quad$ : Regression coefficient of each independent variable

TO : Trade openness

PG : Population growth

INF : Inflation

ln EXR : Exchange rate (in natural log)

GFCF : Gross fixed capital formation

$\varepsilon \quad:$ : Coefficient of error at time $\mathrm{t}$ for unit cross section $\mathrm{i}$

t : Time

i : Country

IV. RESULTS AND DISCUSSION

Results of Regression Test

Table 2 .

Results of Hausman Test

\begin{tabular}{|c|c|c|c|}
\hline Test Summary & Statistic & Chi-Sq. d.f. & Prob. \\
\hline Cross-section random & 43.4155 & 5 & 0.0000 \\
\hline
\end{tabular}

Source: Eviews 11 (2021), the data processed by the author

The results of the Hausman test in table 2 show a p-value of 0.0000 which is smaller than the significance level (0.05), meaning that the right model to be used in this study is the Fixed Effect Model (FEM).

Table 3.

Results of Panel data regression-Fixed Effect Model

\begin{tabular}{|l|c|c|c|c|c|}
\hline \multicolumn{1}{|c|}{ Variable } & coefisien & Std. Error & t-Statistik & Prob. & Remarks \\
\hline Constant & 8,49 & 2,772 & 2,975 & 0,0031 & \\
\hline POP & $-0,888$ & 0,140 & $-6,307$ & 0,0000 & Significant \\
\hline TO & 0,037 & 0,013 & 2,878 & 0,0041 & Significant \\
\hline INF & 0,020 & 0,016 & 1,248 & 0,2123 & not Significant \\
\hline ln EXR & $-2,378$ & 0,543 & $-4,372$ & 0,0000 & Significant \\
\hline GFCF & 0,160 & 0,033 & 4,744 & 0,0000 & Significant \\
\hline$R^{2}$ & \multicolumn{7}{|l}{} & \\
\hline
\end{tabular}

Source: Eviews 11 (2021), the data processed by the author 
The regression equation form in table 4.3 above can be written as follows:

GDPg $=8,249-0,89 \mathrm{POP}_{\text {it }}+0,037 \mathrm{TO}_{\text {it }}+0,02 \mathrm{INF}_{\text {it }}-2,378 \ln \mathrm{EXR}_{\text {it }}+0,16 \mathrm{GFCF}_{\text {it }}+\mathrm{e}_{\text {it }}$

The constant value of 8.249 means that when all independent variables have a value of 0 , then the value of GDP growth per capita is a constant of 8.249 percent. The coefficient value of population growth of -0.89 indicates that an increase in population growth of 1 percent will cause a decrease in GDP per capita of 0.89 percent assuming that other variables are constant. The trade openness coefficient value of 0.037 can be interpreted that an increase in trade openness by one percent will increase the GDP per capita by 0.037 percent assuming that other variables are constant. The inflation coefficient value of 0.02 means that an increase in inflation of one percent will result cause an increase in GDP per capita of 0.02 percent assuming that other variables are constant. The exchange rate coefficient of $-2,378$ indicates that one percent increase in the exchange rate in will result in a decrease in economic growth of $-2,378 / 100$ or -0.023 percent, cateris paribus. The coefficient investment value of 0.16 indicates that an increase in the investment value of one percent will result in an increase in tehe conomic growth of 0.16 percent, cateris paribus.

\section{F-test Results (simultaneous)}

To know whether the independent variables simultaneously have a significant effect on the dependent variables, the results of data processing of Eviews 11 on the F test are used. The results of data processing in table 4.5 of the F statistical value shows a value of 0.000 , so, as the probability is smaller than 0.05 , this indicates that the independent variables, namely population growth, trade openness, inflation, exchange rates and investment, have a significant simultaneous effect on the economic growth (GDP). per capita) OIC members.

\section{T-test Results (partial)}

The population growth variable (POP) has a t-statistic value of -6.307078 with a probability level of 0.0000 which is less than 0.05 , meaning that the population growth variable (POP) has a significant negative effect on economic growth (GDP per capita) or in other words $\mathrm{H} 0$ is rejected and $\mathrm{H} 1$ is accepted. Income per capita is calculated as income divided by population, thus increasing population in OIC countries will decrease per capita income because the divisor value is higher. The trade openness variable has a t-statistic value of 2.878663 with a probability level of 0.0041 where the probability value is less than 0.05 , so that there is a significant positive effect of the trade openness (TO) variable on economic growth (GDP per capita).

The results of t-statistics In the inflation variable show a value of 1.248802 and a probability value of 0.2123 . Because the probability value exceeds the value of 0.05 , the inflation variable has no significant effect on the GDP per capita or economic growth. The t-statistic value of the exchange rate variable (ln EXR) is -4.372980 with a significant probability value of 0.0000 which is smaller than 0.05 , so it can be concluded that the exchange rate variable has a significant effect on economic growth per capita but it has a negative relationship. The investment variable with the proxy of gross fixed capital formation (GFCF) with a t-statistic value of 4.744474 and a significance probability value of 0.0000 affects significantly and has a positive relationship on the economic growth (GDP per capita).

\section{The Effect of Population Growth on Economic Growth}

Population growth, as seen in the regression results in table 3, negatively and significantly affects the GDP per capita variable of 40 OIC member countries. The results of this study are in line with research by Bucci and Raurich (2016), Yao et al., (2013), Hasan (2010) and Banerjee (2012) where population growth negatively affects economic growth. According to Hasan (2010), the high population growth tends to slow down the economic growth and leads to a serious economic consequence, especially in countries with low income. As the population problem and economic growth are closely related to the issue of the minimum wage and when population growth increases the labor force, this will lead to a decrease in wages (Tsen and Furuoka, 2005). According to Ali et al., (2013), for developing countries rapid population growth will reduce savings at household and national levels. One of the reasons for the high population growth is the high fertility rate, so that the number of dependents per worker increases due to the relatively large proportion of the population under working age. The burden of dependence then creates pressure on households to tend to 
consume in the present rather than to save. Becker et al., (1999) also explain that high population growth can reduce per capita income through diminishing marginal productivity.

God made human beings as caliphs on earth as a mandate basically to manage and make good use of what is available on earth in accordance with sharia principles (Hayati, 2016). Humans are required to be able to maintain the balance of nature because humans have been given the heart and mind to support the function of the caliphate. The high level of GDP per capita does not immediately describe equitable growth in a country. Meanwhile, Islam teaches that economic growth does not only prioritize the amount of output produced but also the equitable and fair distribution for all human beings. Without justice, economic development does not become perfect. The scarcity of natural resources will not occur if humans can utilize and distribute the resources wisely because Allah has granted and guaranteed sustenance for all His creatures according to His word in QS. Ibrahim verse 34 and QS. Hud verse 6 which read:

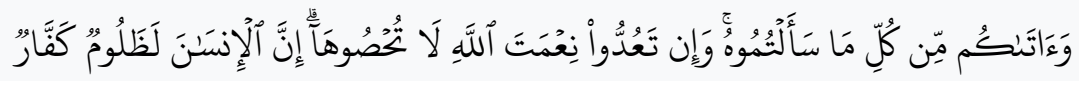

Meaning: "And He has granted you all that you asked Him for. And if you tried to count Allah's blessings, you would never be able to number them. Indeed humankind is trully unfair and ungrateful (for Allah's blessings)."

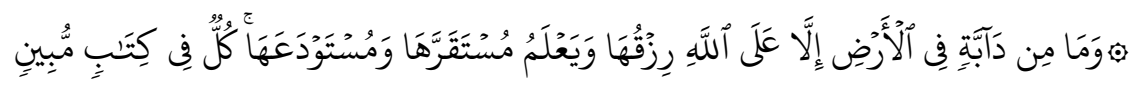

Meaning:"And there is no moving creature in the earth but on Allah is the sustenance of it, and $\mathrm{He}$ knows its place of dwelling and its depository. All is (written) in clear Kitab (Lauh Mahfuzh." (Saheeh International)

\section{The Effect of Trade Openness on Economic Growth}

In accordance with the regression results in table 3, the variable of trade openness shows a positive and significant relationship to the economic growth in the OIC Countries. These results are in line with research conducted by Razmi and Refaei (2013) where they found that the effect of trade openness has a positive and significant relationship to economic growth in several Middle East and East Asian countries. Economists state that all forms of open trade are profitable, in addition, especially with specialization in trade based on the theory of Adam Smith, Ricardo and HeckscherOhlin (Ismail, 2012: 373). According to Sach and Warner (1995) in the journal Ertimi et al., (2016), the more open an economy is to international markets, the higher the growth rate is. Trade between countries will help promote supply-side growth through more efficient use of resources, encouraging competition, and an increase in the flow of ideas and knowledge (Parikh, 2006). A result, this will increase output, export and import growth, as well as improve economic welfare.

Results in table 4.3 shows there is a positive but not significant relationship between the inflation variable and economic growth. Inflation can boost economic growth when the inflation rate is at a moderate level (Baharumshah et al., 2016). Khan and Sanhadji (2013) analyzed the effect of inflation on economic growth using a threshold value in industrialized and developing countries. The inflation rate would slow down the economic growth when it was above the threshold value of 1-3 percent for industrialized countries, and 11-12 percent for developing countries.

In Islam, trade between countries is carried out on the basis of ukhuwah (brotherhood) ties. The principle of ukhuwah itself is essentially a universal value in social interaction and harmonization of the interests of the parties involved to obtain a benefit in general with the spirit of mutual help (Ikit et al., 2018). Transactions based on the principle of ukhuwah will uphold the value of togetherness in obtaining benefits so that transactions will not benefit one party at the expense of another party. Through the value of brotherhood, business people will always be careful and avoid practices that are not in accordance with the Shari'a such as buying and selling tadlis, gharar, ihtikar, and so on. Islam encourages its people to carry out trading activities through QS. Al-Jumu'ah verse 10:

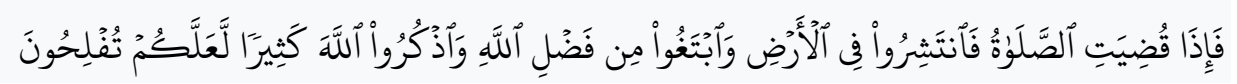

Meaning: "Once the prayer is over, disperse throuh out the land (earth) and seek the bounty of Allah. And remember Allah often so you may be successful." (Saheeh International) 
The above verse commands people to walk on the earth in search of Allah's sustenance and bounty on earth and from one place to another for the purpose of trade between countries. Meanwhile, based on the data from SESRIC (2020) for the last three years 2016-2019, the value of intra-OIC exports increased by more than $30 \%$ which is a significant achievement, although this figure is still below the total value recorded in 2012. Trade flows among the OIC countries themselves during 2012-2019 were still struggling at 18\% and 19\%, meaning that the growth of trade flows among OIC member countries was very slow so that it was still far from the achievement targets set out in the OIC Ten-Year Program of Action (OIC) agenda. -2025), as much as $25 \%$, The involved parties and governments in the OIC countries, therefore, are to encourage bilateral and multilateral trade as well as investment agreements and cooperation among OIC countries. On the other hand, the slowdown in trade growth in the OIC is partly due to a lack of attention to diversification and competitiveness of tradable products

\section{The Effect of Inflation on Economic Growth}

Based on the results of the partial hypothesis test or the t-test of the inflation variable (INF), the t-statistic results show a value of 1.248802 and a probability value of 0.2123 , meaning that inflation has no effect on GDP growth per capita in the OIC Countries.

Inflation can effect economic growth positively when the inflation rate is at a moderate level (Baharumshah et al., 2016). Khan and Sanhadji (2013) analyzed the effect of inflation on growth using a threshold value in industrialized and developing countries which showed that the inflation rate would slow down the economic growth when the developing countries have the inflation above the threshold value of 11-12 percent.

In Islam Inflation can be carried out by controlling the consumption pattern of each individual. Furqani (2017) in his journal explains that Allah forbids tabdhir acts which means wasteful consumption. This wasteful characteristic includes consuming goods beyond the need and being exaggerated. QS. Al-Isra verses 26-27 explains that being wasteful is an act hated by Allah:

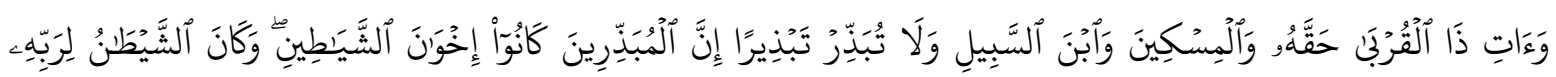

$$
\text { كَفُورًَا }
$$

Meaning: "And give the relative his right, and also the poor and the traveler, and do not spend (your wealth) wastefully. Indeed, the wasteful are brothers of the devils (satan) and satan has been ungrateful to his God." (Saheeh International)

\section{Effect of Exchange Rate on Economic Growth}

In the t-test, the exchange rate variable (ln EXR) generated the t-statistic value of -4.372980 with a significant probability value of 0.0000 meaning that there is a significant negative effect between the exchange rate variable (ln EXR) on economic growth (GDP per capita). The results of this study are in accordance with the results of research from Grauwe and Schnabl (2008), Chirwa and Odhiambo (2016), Abubakar (2015), Gul et al., (2012), Barguellil et al., (2018) and Umaru et al., (2018) that the exchange rate negatively affects economic growth. One of the reasons for the increase in the exchange rate is the support for adequate export growth so that it will increase the demand for the national currency (Rudiawan and Meirinaldi, 2019). The results in this study indicated that the exchange rate has a negative effect on economic growth due to the high exchange rate indicated by the weak value of the domestic currency against the US dollar which will directly have an impact especially on the increasingly expensive prices of imported goods, including imported raw materials used to create domestic products, which in the end will increase the price of goods and reduce people's purchasing power.

\section{The Effect of Investment (Gross Fixed Capital Formation) on Economic Growth}

The results of the t-test of the t-statistical value on the investment variable give a value of 4.744474 and a significance probability value of 0.0000 , meaning that there is a significant positive effect of the investment variable (GFCF) on economic growth (GDP per capita). Investment is one of the main sources of economic growth through increasing the capital stock. Because through GFCF (Gross Fixed Capital Formation) which is calculated based on investment from the purchase of capital goods and infrastructure, it can encourage output growth, productivity and quality of production 
which can finally encourage economic growth and increase employment (Sulistiawati, 2012). The results of this study are in accordance with the results of research by Koirala (2018), Yalçınkaya et al., (2017), Abbas et al., (2020), Destek (2016) showining that gross fixed capital formation significantly affects and promotes economic growth. In 2017, $28 \%$ of the total GDP generated in OIC countries was invested in productive assets, meanwhile the total gross domestic fixed capital formation of OIC Countries in global markets showed an increase of 3.7 percent since 2000 and 0.4 percent from in 2010 to $9.3 \%$ in 2017 (SESRIC, 2019).

Islam commands its followers to carry out lawful (halal) activities and manage their wealth according to what Allah and His Messenger have decreed. Sano (2000) in the journal of Zaky et al., (2015) asserts that investment is the activity of individuals or organizational entities in managing wealth in accordance with sharia principles to obtain profits in order to carry out their responsibilities as caliphs on earth. Generally, someone who has excess wealth must utilize it for community empowerment to help improve the quality of life of the underprivileged through productive efforts as stated in QS. Al-Baqarah verse 261:

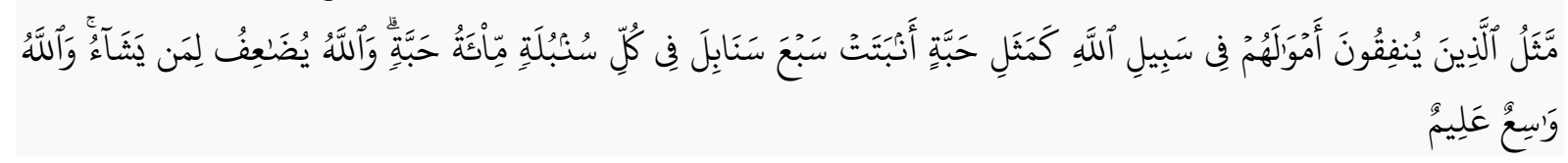

Meaning: "The example of those who spend their wealth in the way of Allah is like a seed of grain which grows seven spike; in each spike is a hundred grains. And Allah multiplies for whom he wills. And Allah is all-Encompassing (most Capable) and Knowing." (Saheeh International)

Infaq can also be defined as spending one's possessions to be used in the way of goodness. The above verse Indirectly explains that the assets issued in order to be invested and managed productively will grow more and more in value and develop. With the wealth donated, it is like helping many people to improve their quality of life (Sakinah, 2015).

\section{CONCLUSION}

The results of this study indicate that population growth, trade openness, exchange rates and investment partially have a significant effect, while inflation has no significant effect on the economic growth in the 40 OIC Countries. Based on the results of the statistical F test, it shows that the variables of population growth, trade openness, inflation, exchange rates and investment simultaneously have a significant effect on the economic growth.

It is expected that academics and potencial further research can benefit from this study and make it as a repository of knowledge and a source of reference in order to develop new research related to the effect of population growth and trade openness on the economic growth of the OIC countries by using different benchmarks. For the government or related parties, it is expected that this study can be utilized as material for evaluation and consideration in making policies and formulating strategies to stimulate economic growth in the future. Based on the results of this study, the government and related parties are expected to be able to control the rate of population growth and to encourage the international trade sector, considering that the level of trade openness in the OIC countries is still below its potential.

\section{REFERENCES}

Abbas, Q., Nurunnabi, M., Alfakhri, Y., Khan, W., Hussain, A., \& Iqbal, W. (2020). The role of fixed capital formation, renewable and non-renewable energy in economic growth and carbon emission: A case study of Belt and Road Initiative project. Environmental Science and Pollution Research, 27(36).

Abubakar, A. B. (2015). Impact of International trade on economic growth in India. International Journal of Financial Research, 6(3). https://doi.org/10.5430/ijfr.v6n3p163

Ali, S., Ali, A., \& Amin, A. (2013). The impact of population growth on economic development in Pakistan. Middle East Journal of Scientific Research, 18(4), 483-491. https://doi.org/10.5829/idosi.mejsr.2013.18.4.12404

Aprianto, N. E. K. (2017). Kebijakan distribusi dalam pembangunan ekonomi Islam. Jurnal Hukum 
Muharromy, et al/Jurnal Ekonomi Syariah Teori dan Terapan Vol. 8 No. 5 September 2021: 537-547

Islam, 14(2), 73. https://doi.org/10.28918/jhi.v0i0.693

Badan Kependudukan dan Keluarga Berencana. (2012). Analisis Dampak Laju Pertumbuhan Penduduk dan Kualitas Hidup Manusia di Indonesia.

Baharumshah, A. Z., Slesman, L., \& Wohar, M. E. (2016). Inflation, inflation uncertainty, and economic growth in emerging and developing countries: Panel data evidence. Economic Systems, 40(4), 638-657. https://doi.org/10.1016/j.ecosys.2016.02.009

Banerjee, R. (2012). Population growth and endogenous technological change: Australian economic growth in the long run. Economic Record, 88(281), 214-228. https://doi.org/10.1111/j.14754932.2011.00784.x

Barguellil, A., Ben-Salha, O., \& Zmami, M. (2018). Exchange rate volatility and economic growth. Journal of Economic Integration, 33(2), 1302-1336.

Becker, G. S., Glaeser, E. L., \& Murphy, K. M. (1999). Population and economic growth. The American Economic Review, 89(2).

Bucci, A., \& Raurich, X. (2016). Population and economic growth under different growth engines. German Economic Review, 1-30. https://doi.org/10.1111/geer.12092

Chirwa, T. G., \& Odhiambo, N. M. (2016). Macroeconomic determinants of economic growth: A review of international literature. South East European Journal of Economics and Business, 11(2), 33-47. https://doi.org/10.1515/jeb-2016-0009

Destek, M. A. (2016). Natural gas consumption and economic growth: Panel evidence from OECD countries. Energy, 114, 1007-1015. https://doi.org/10.1016/j.energy.2016.08.076

Dzian, M., H. Paluš., \& Parobek, J. (2020). The impact of globalisation on the Slovak timber trade. Sustainability of Forest-Based Industries in the Global Economy - Proceedings of Scientific Papers, 45-49.

Ertimi, B. E., Albisht, E. M., \& Oqab, B. A. (2016). The Impact of corruption on economic growth in oic countries the impact of corruption on economic growth in OIC Countries. International Journal of Economics and Finance, 8(9). https://doi.org/10.5539/ijef.v8n9p91

Furqani, H. (2017). Consumption and morality: Principles and behavioral framework in Islamic economics. Journal of King Abdul Aziz University: Islamic Economics, 30, 89-102.

Grauwe, P. D., \& Schnabl, G. (2008). Exchange rate stability, inflation, and growth in (South) Eastern and Central Europe. Review of Development Economics, 12(3), 530-549. https://doi.org/10.1111/j.1467-9361.2008.00470.x

Gul, H., Mughal, K., \& Rahim, S. (2012). Linkage between monetary instruments and economic growth. Universal Journal of Management and Social Sciences, 2(5).

Haller, A. (2012). Concepts of economic growth and development. Challenges of crisis and of knowledge. Economy Transdisciplinarity Cognition, 15(1).

Halwani, H. (2012). Ekonomi internasional dan globalisasi ekonomi. Surabaya: Ghalia Indonesia.

Hasan, M. S. (2010). The long-run relationship between population and per capita income growth in China. Journal of Policy Modeling, 32(3), 355-372. https://doi.org/10.1016/j.jpolmod.2009.09.005

Hatmanu, M., Cautisanu, C., \& Ifrim, M. (2020). The impact of interest rate, exchange rate and european business climate on economic growth in Romania: An ARDL approach with structural breaks. Sustainability (Switzerland), 12(7). https://doi.org/10.3390/su12072798

Hayati, M. (2016). Investasi menurut perspektif ekonomi Islam. IKONOMIKA Jurnal Ekonomi dan Bisnis Islam, 1(April), 66-78.

Ikechi, K. S., \& Emmanuel, N. C. (2015). Capital expenditures and gross fixed capital formation in Nigeria. Research Journal of Finance and Accounting, 6(12), 188-198.

Ikit, Artiyanto, H., \& Saleh, M. (2018). Jual beli dalam perspektif ekonomi Islam. Yogyakarta: Penerbit Gava Media.

Ismail, P. Z. (2012). Teori ekonomi. Bandung: Dharma Ilmu.

Jhingan, M. L. (2000). Ekonomi pembangunan dan perencanaan. Jakarta: Rajawali Press.

Khalid, M. A. (2016). The impact of trade openness on economic growth in the case of Turkey. Research Journal of Finance and Accounting, 7(10).

Khan, M. S., \& Ssnhadji, A. S. (2013). Threshold effects in the relationship between inflation and growth. IMF Staff Papers, 48(1), 1-21.

Kharis, M. M. (2011). Pengaruh faktor-faktor kependudukan terhadap pertumbuhan ekonomi di 
kabupaten Pemalang. Skripsi tidak diterbitkan. Semarang: Universitas Diponegoro.

Koirala, S. (2018). An analysis of the impact of real effective exchange rate on economic growth of Nepal. Pravaha, 24(1), 206-216. https://doi.org/10.3126/pravaha.v24i1.20239

Mankiw, G. N. (2011). Makroekonomi. Terjemahan dari Macroeconomics 6th (ed.); 6th ed.).

Milani, F., \& Park, S. H. (2015). The Effects of Globalization on Macroeconomic Dynamics in a Trade-Dependent Economy : the Case of Korea. Economic Modelling, 48.

Nurul Huda, dkk. (2017). Ekonomi Pembangunan Islam. Kencana Prenada Media Press.

Peterson, E. W. F. (2017). The role of population in economic growth. SAGE Open, 7(4). https://doi.org/10.1177/2158244017736094

Razmi, M. J., \& Refaei, R. (2013). The effect of trade openness and economic freedom on economic growth: The case of middle east and East Asian countries. International Journal of Economics and Financial Issues, 3(2), 376-385.

Rudiawan, H., \& Meirinaldi. (2019). Dampak faktor-faktor makro ekonomi terhadap pertumbuhan produk domestik bruto Indonesia. Jurnal Ekonomi, 21(1). https://doi.org/10.37721/je.v21i1.535

Sakinah, S. (2015). Investasi dalam Islam. IQTISHADIA: Jurnal Ekonomi \& Perbankan Syariah, 1(2), 248. https://doi.org/10.19105/iqtishadia.v1i2.483

Sugiyono. (2016). Metode penelitian kuantitatif kualitatif dan R\&D. Bandung: CV. Alfabeta.

Sukirno, S. (2013). Makro ekonomi teori pengantar. Jakarta: Raja Grafindo Persada.

Sulistiawati, R. (2012). Pengaruh investasi terhadap pertumbuhan ekonomi dan penyerapan tenaga kerja serta kesejahteraan masyarakat di provinsi di Indonesia. Jurnal Ekonomi Bisnis dan Kewirausahaan, 3(1), 29-50.

Todaro, M. P., \& Smith., S. C. (2013). Pembangunan ekonomi. Jakarta: Erlangga.

Tsen, W. H., \& Furuoka, F. (2005). The relationship between population and economic growth in Asian Economies. Asean Economic Bulletin, 22(3), 314-330. https://doi.org/10.1355/ae22-3e

Umaru, H., A, A. N., \& Davies, N. O. (2018). The effects of exchange rate volatility on economic growth of West African english-speaking countries. International Journal of Academic Research in Accounting, Finance and Management Sciences, 8(4), 131-143. https://doi.org/10.6007/IJARAFMS/v8-i4/5470

Vorlak, L., Abasimi, I., \& Fan, Y. (2019). The impacts of exchange rate on economic growth in Cambodia. International Journal of Applied Economics, Finance and Accounting, 5(2), 7883. https://doi.org/10.33094/8.2017.2019.52.78.83

Yalçınkaya, Ö., Hüseyni, İ., \& Çelik, A. K. (2017). The impact of total factor productivity on economic growth for developed and emerging countries: A second-generation panel data analysis. The Journal of Applied Economic Research, 4, 404-417. https://doi.org/10.1177/0973801017722266

Yao, W., Kinugasa, T., \& Hamori, S. (2013). An empirical analysis of the relationship between economic development and population growth in China. Applied Economics, 45(33), 37-41. https://doi.org/10.1080/00036846.2013.795284

Zaky, M., Asyadi, M., Zainodin, M., Saja, M., Nawi, S. M., Firdaus, M., \& Erna, N. (2015). Managing investment in the light of quran and sunnah: Textual analysis. Procedia Economics Anf Finance, 31(15), 380-386. https://doi.org/10.1016/S2212-5671(15)01213-7 